\title{
Öğretmen Adaylarının Özel Eğitime İlişkin Metaforik Algiları
}

DOI: 10.26466/opus.676175

$*$

\author{
Özlem Altındağ Kumaş* - Sedef Süer ** \\ * Dr., Dicle Üniversitesi/Ziya Gökalp Eğitim Fakültesi, Özel Eğitim Bölümü, Diyarbakır/Türkiye \\ E-Posta: ozlemmaltindag@gmail.com \\ ORCID: 0000-0002-6104-2381 \\ ** Dr., Dicle Üniversitesi, Ziya Gökalp Eğitim Fakültesi, Eğitim Bilimleri Böl., Diyarbakır/Türkiye \\ E-Posta: sedefsuer@gmail.com \\ ORCID: 0000-0002-1833-9286
}

\section{Öz}

Öğretmen adaylarının özel ĕğitime ilişkin metaforik algllarının incelendiği bu çalışma 2019-2020 eğitim -öğretim yılında toplam 85 öğretmen adayının katılımıyla gerçekleştirilmiştir. Çalışmaya Eğitim Fakültesi'nin İngilizce, Türkçe, Sosyal Bilgiler ve Resim-iş öğretmenliği bölümü programlarında eğitim gören 4. sinıf öğrencileri dahil edilmiştir. Veriler öğretmen adaylarından "Özel eğitim ..... gibidir/benzer, çünkü ......" ifadelerin tamamlamasıyla elde edilmiştir. Toplanan veriler içerik analizi yöntemi ile analiz edilmiş ve yorumlanmıştır. Çalışmanın bulgularında öğretmen adaylarının ürettikleri 85 metafor "İhtiyaç olarak özel eğitim", "Ĕğitimde fırsat eşitliğini sağlama aracı olarak özel eğitim", "Özel ilgi ve yardım aracı olarak özel eğitim", "Koşulsuz kabul sağlama aracı olarak özel eğitim" ve "Farklılık olarak özel eğitim" olmak üzere toplam 5 tema altında gruplanmıştır. Araştırma sonucunda öğretmen adaylarının "Özel Eğitim'e ilişkin metaforik algilarının olumlu yönde olduğu görülmekle beraber öğretmen adayların kaynaştırma eğitimine yönelik herhangi bir görüş bildirmediğ $i$ belirlenmiştir. Araştırma sonucunda kaynaştırma dersinin ayrı bir ders olarak uygulamal şekilde verilmesi ve bu dersin farklı anabilim dallarında zorunlu ders olarak yaygınlaştırılması önerilmiştir.

Anahtar Kelimeler: Özel eğitim, ögretmen adayları, metaphor analizi 


\title{
Preservice Teachers' Metaphoric Perceptions of Special Education
}

\begin{abstract}
This study examining the preservice teachers' metaphoric perceptions about special education was conducted with the participation of 85 preservice teachers in 2019-2020 academic year. Senior students studying in English teaching, Turkish teaching, Social Studies and Art Teaching programs of an education faculty were included in the study. The required data for the study were obtained by asking the preservice teachers filling a survey form containing the statement of "Special education looks like alan. because .". The obtained data were analyzed and interpreted by using content analysis method. Findings showed that preservice teachers produced 85 metaphors categorized under 5 themes: "Special education as a need", "Special education as a means of ensuring equal opportunities in education", "Special education as a special interest and aid tool", "Special education as a means of providing general acceptance" and "Special education as a differences". The results of the study showed that preservice teachers' metaphoric perceptions about "Special Education" are positive even though they do not touch on the topic of inclusive education. As a result, it is suggested that an inclusive education should be included and expanded as a compulsory course in the programs of different departments.
\end{abstract}

Keywords: Special education, preservice teachers, metaphoric analysis 


\section{Giriş}

Her çocuk bedensel, zihinsel, sosyal özellikleri yönünden bireysel farklılıklar gösterir. Eğer çocuk tüm bu gelişim özellikleri yönünden akranlarıyla ciddi farklılıklar gösteriyorsa, alacağı eğitim hizmetleri de farklılaşabilmektedir. Bu farklılıklar "özel eğitim" hizmetlerine gereksinimi doğurmaktadır. Özel eğitim, özel gereksinimli bireylerin eğitim ihtiyaçlarını karşılamak için özel olarak yetiştirilmiş personel, geliştirilmiş eğitim programları ve yöntemleri ile onların gereksinim ve özelliklerine uygun ortamlarda sürdürülen eğitime denilmektedir (Ataman, 2005). Özel gereksinimli bireylerin eğitimi bireylerin ihtiyaç ve gereksinimleri doğrultusunda kendilerine sağlanan eğitim faaliyetlerinden en üst düzeyde yararlanmalarını sağlamak amacıyla önceden belirlenen ortamlarda yürütülmektedir. $\mathrm{Bu}$ ortamlar bireylerin akranları ile aynı ortamı paylaştığı kaynaştırma sınıfları olabileceği gibi kendisiyle benzer özellikler taşıyan ve eğitim gereksinimleri aynı olan akranlarıyla ayrı okullar da olabilmektedir (Çakıroğlu, 2018).

Özel eğitimin temel ilkeleri 573 sayılı Özel Eğitim Hakkında Kanun Hükmünde Kararname ve 2005 tarihli 5378 sayılı Özürlüler Kanunu, engelli tanısı almış çocukların özel eğitim kurumlarında eğitim alabileceğini ve eğitim giderlerinin de devlet tarafından ödeneceğini hükme bağlamıştır. Ülkemizde, 2002 yılında 15 bin 381 öğrenci özel eğitim alırken, 2016 yılında bu sayının 44 bin 278'e yükseldiği bildirilmektedir (Millî Eğitim Bakanlığı, 2015). Bu bireylerin yetersizlikleri ise kendine özgüdür ve tanılanması, ihtiyaçlarının belirlenmesi, eğitimlerinde daha uygun düzenleme ve planlamaya yol gösterici olması için ortak özellikleri ve eğitim ihtiyaçlarına göre sınıflandırma yapılmaktadır. Özel eğitim gerektiren bireyler genellikle şu gruplar altında toplanmaktadır (Cavkaytar ve Diken, 2005): Zihinsel yetersizliği olan bireyler. Görme yetersizliği olan bireyler. İşitme yetersizliği olan bireyler. Ortopedik yetersizliği olan bireyler. Dil ve konuşma güçlügü olan bireyler. Öğrenme güçlügü olan bireyler. Duygusal, davranışsal ve uyum güçlüğü olan bireyler. Otizmli bireyler. Üstün zekâ ve üstün yeteneği olan bireyler.

Özel eğitim, özel gereksinimli bireylerin toplumda bağımsız bir yaşam sürmesinde oldukça önemli ve ihmal edilmemesi gereken bir konudur. Özel eğitimin gerçekleştirilmesi için tanımından da anlaşılacağı gibi, özel olarak eğitilmiş personel gerekmektedir. Özel eğitim süreçlerinde fizyoterapistler- 
den rehberlik ve psikolojik danışmanlara kadar birçok farklı profesyonel olabilir. Bu profesyoneller arasında, öğretmenler önemli bir rol oynamaktadır (Ergül, Baydık ve Demir, 2013). Özellikle öğretmen adaylarının mesleğe geçmeden önce genelde özel eğitim, özelde kaynaştırma hakkında bilgi sahibi olmaları özel gereksinimli bireylerin ihtiyaçlarını karşılamada önemlidir.

Öğretmen yetiştirme programlarının hemen her bölümünde son sınıf öğrencilerin aldığı özel eğitim dersinin amacı şu şekilde açıklanmaktadır: Özel eğitimdeki temel kavramları doğru kullanan; özel eğitimin tarihsel sürecini açıklayan; alandaki yasal mevzuatı bilen; özel gereksinimli öğrencilerin değerlendirilmesi, bireysel eğitim programları hazırlanması ve kaynaştırma sürecini kavrayan; zihinsel yetersizlik, işitme yetersizliği, görme yetersizliği, fiziksel yetersizlikler/süreğen hastalıklar, dil ve konuşma bozukluğu, öğrenme güçlüğü, duygu davranış bozukluğu, otistik bozukluk, çoklu yetersizlik ya da üstün zekânın tanımını, özelliklerini ve bu özelliklere sahip öğrencilerin eğitim yaklaşımlarını tanıyan ve sınıfında bu öğrenciler için öğretimsel düzenlemeler yapabilen bireyler yetiştirmek (YÖK, 2019). Dolayısıyla öğretmen adaylarının özel eğitime yönelik ilk algıları bu dersi almaya başladıktan itibaren oluşmakta ve özel eğitim hizmetlerinin başarısı, bu hizmetleri sağlayan personelin kalitesine, dolayısıyla öğretmen kalitesine bağlanmaktadır (Vuran, 2013). Ayrıca özel gereksinimli öğrencilere yönelik olumlu tutumların öğretmen adaylarının özel eğitim ve kaynaştırmaya yönelik bilgileri ile doğrudan ilişkili olduğu da belirtilmektedir (Bek, Gülveren ve Başer, 2009; Kim, 2011; Orel, Zerey ve Töret, 2004; Şahin ve Güldenoğlu, 2013).

Türkiye'de 1980 yılından itibaren kaynaştırma uygulamaları başlatılmıştır. Bu uygulamaların başlaması ile özel gereksinimli çocukların genel eğitim sınıflarına yerleştirilme oran her geçen gün artmaktadır (MEB, 2015). Kaynaştırma uygulamalarının özel gereksinimli öğrenciler için yasal bir hak olmasından sonra ülkemizde, her sinif seviyesinde hemen hemen tüm okullarda bir ya da birden fazla özel gereksinimli öğrenci yer alabilmektedir (Akalın, 2015). Dolayısıyla her sınıf seviyesinde görev alan öğretmenlerin mesleğe başlamadan önce özel eğitim/kaynaştırma hakkında bilgi sahibi olması kaynaştırma uygulamalarının etkili bir şekilde yürütülmesinde ve özel gereksinimli öğrencilerin ihtiyaçlarının karşılanmasında önemli görülmektedir (Vuran, 2013). 
Kaynaştırma uygulamalarının etkili şekilde yürütülmesinde birincil sorumlu olan öğretmenlerin meslek hayatına başlamadan önce özel eğitime ilişkin olumlu algı ve tutum geliştirmeleri önemlidir. Alan yazın incelendiğinde öğretmen adaylarının özel eğitime ilişkin tutum ve algılarını inceleyen çalışmalar (Atay, 1995; Gökdere, 2012; Fırat Durdukoca, 2015; Özbaba, 2000; Soyyiğit, 2013; Yazıcıoğlu, 2019) olmasına karşın öğretmen adaylarının özel eğitime ilişkin algılarını daha özgür, yaratıcı ve karmaşık şekilde ele alan niteliksel çalışmalara rastlanılmamıştır. Öğretmen adaylarının özel eğitim ile ilgili algılarının daha az sözcük kullanarak daha etkili bir şekilde ortaya koymasını sağlayan metaforların (Girmen, 2007) öğretmen adaylarının özel eğitime yönelik algılarına ilişkin daha net bilgi vereceği düşünülmektedir. Dolayısıyla bu araştırmanın amacı öğretmen adaylarının özel eğitime ilişkin algılarını metaforlar aracılı̆̆ıyla tespit etmektir. Bu temel amaç doğrultusunda aşağıdaki sorulara cevap aranmıştır:

1. Öğretmen adaylarının özel eğitim kavramına ilişkin sahip oldukları metaforlar nelerdir?

2. Ortaya çıkan metaforlar ortak özellikleri açısından hangi kavramsal kategoriler altında toplanmıştır?

\section{Yöntem}

Çalışmanın bu bölümünde, araştırma deseni, çalışma grubu, veri toplama aracı, veri toplama süreci ve elde edilen verilerin analizine ilişkin bilgilere yer verilmiştir.

\section{Araştırma Deseni}

Eğitim fakültesi son sınıfında özel eğitim dersi alan öğretmen adaylarının özel eğitim dersine yönelik derin ve ayrıntılı görüş ve düşüncelerini ortaya çıkarmayı amaçlayan bu çalışma olgu bilim (fenomenoloji) deseninde tasarlanmıştır. Olgu bilim (fenomenoloji), sosyal gerçekliğe dayanan bir duruma ilişkin insan deneyimlerinden hareketle oluşturulan bakış açısını inceleyen bir nitel araştırma yöntemidir (Ersoy, 2017: 83). 


\section{Çalışma Grubu}

Bu çalışma 2019-2020 eğitim öğretim güz yarıyılında, bir devlet üniversitesinin eğitim fakültesi Türkçe, İngilizce, Sosyal Bilgiler ve Resim-iş öğretmenliği bölümü özel eğitim dersini alan son sinıf öğrencileri ile yürütülmüştür. Çalışma kapsamında İngilizce, Türkçe, Sosyal Bilgiler ve Resim-iş öğretmenliği bölümlerinde özel eğitim dersini ve çalışmaya katılım gösterme konusunda gönüllülük gösteren toplam 85 (52 kadın ve 33 erkek) öğrenciye ulaşılmıştır. Çalışmada yer alan katılımcılara ilişkin betimsel istatistik sonuçları Tablo 1. de gösterilmiştir.

Tablo 1. Çalışma kapsamına alınan katılımcılara ilişkin betimsel istatistik sonuçları

\begin{tabular}{llllll}
\hline Cinsiyet & Kadın & Erkek & Toplam & & \\
\hline $\mathbf{N}$ & 52 & 33 & 85 & & \\
$\mathbf{\%}$ & 61,2 & 38,8 & 100 & Resim-iş & Toplam \\
\hline Bölüm & İngilizce & Türkçe & Sosyal Bilgiler & 14 & 85 \\
\hline $\mathbf{N}$ & 13 & 28 & 30 & 16,5 & 100 \\
\hline & 15,3 & 32,9 & 35,3 & & \\
\hline
\end{tabular}

\section{Verilerin Toplanması}

Araştırma verileri 2019-2020 eğitim öğretim yılı güz yarıyılında, ilgili eğitim fakültesindeki özel eğitim dersi kapsamında anlatılan "Özel Eğitimle ilgili Temel Kavramlar" konusunun tamamlanmasının ardından anket formu aracılığıyla toplanmıştır. Araştırmaya gönüllü katılım gösteren öğretmen adaylarına 3 kişisel bilgi ve "Özel eğitim............gibidir, çünkü............." ibaresinden oluşan anket formu oluşturulmuş ve biri özel eğitim ikisi eğitim programları alanında uzman 3 öğretim elemanına görüş belirtmesi için sunulmuştur. Uzmanlardan gelen dönütler neticesinde anket formu üzerinde gerekli düzeltmeler yapılmış ve öğretmen adaylarına uygulanmıştır. Öğretmen adaylarından anket formunda yer alan kişisel bilgileri (cinsiyet, bölüm ve sınıf düzeyi) ve özel eğitime ilişkin metaforu (canlı/ cansız fark etmeksizin) düşünerek doldurmaları istenmiştir. Anket formunu doldurmaları için öğretmen adaylarına 20 dakika süre verilip, bu sürecin ardından doldurulmuş anket formları ilgili öğretim elemanı tarafından toplanmış ve araştırmada temel veri kaynağı olarak kullanılmıştır. 


\section{Verilerin Analizi ve Yorumlanması}

Araştırmada elde edilen anket formları öncelikle incelenmiştir. Eksiksiz doldurulduğu tespit edilen toplam 85 öğretmen adayından elde edilen veriler numaralandırılarak bilgisayar ortamına aktarılmıştır. Elde edilen verilerin analizinde içerik analizi yöntemi kullanılmıştır. İçerik analizi, nitel yöntemle elde edilmiş bir metin içinde tekrar eden kelime veya temaların belirlenmesi (Patton, 2014) olarak ifade edilmektedir. İçerik analizi yapılırken, Saban (2008), Aydın ve Ünaldı (2010), Uçuş (2016) ve Beyoğlu ve Ergin (2019) tarafından yapılan çalışmalardan yararlanarak beş adımda analiz edilmiştir. Bu aşamalar sırasıyla: (1) adlandırma aşaması, (2) eleme aşaması,

(3) kategori geliştirme aşaması, (4) geçerlik ve güvenirliği sağlama aşaması (5) verileri bilgisayar ortamına aktarma aşamasıdır.

Adlandırma aşaması: Nitel veri yapısı itibariyle hacimce çok büyük olduğundan (Strauss, 1987) nitel ağırlıklı verilerle yürütülen çalışmalarda veri analizi verilerin düzenlenmesi ve indirgenmesi süreci diğer bir ifadeyle kodlanması ile başlanmaktadır (Wiersma, 1995). Bu sebeple bu araştırmada elde edilen anket formları öncelikle incelenip düzenlenip kodlanmıştır. Nitel analizlerde gerçekleştirilen ilk kodlama veri setine ilişkin sınırlı bir çıkarımda bulunmaya olanak tanıdığından bu ilk kodlama sadece betimleyici nitelikte olup analizi başlatan motivasyon aracı görevindedir (Baltacı, 2017).

Eleme aşaması: $\mathrm{Bu}$ aşamada araştırmacılar her bir anket formunu tek tek okuyup üretilen metaforun imgesi, konusu ve kaynağı incelenerek aralarındaki ilişki mantıksal tutarlılık açısından incelenmiştir. Eksiksiz doldurulduğu tespit edilen toplam 85 öğretmen adayından elde edilen veri formu elde edilmiştir.

Geliştirme Aşaması: Bu aşamada öğretmen adaylarının ürettikleri metaforları olası kategorilere ayırma çalışması yürütülmüştür. Bunun için araştırmacılar her bir anket formunu tek tek okuyup öğretmen adaylarının özel eğitime ilişkin bakış açılarındaki ortak noktalara ilişkin notlar almıştır. Alınan notlar ortak temalar altında toplanmış ve ikinci bir kodlama yapılmıştır. Araştırmacılar tarafından ayrı ayrı kodlanan veriler öğretmen adaylarının belirttiği açıklama ifadeleriyle birlikte okunup ilgili tema altında toplanırken 
üzerinde görüş birliğine varılamayan kod ve temalar için alan yazındaki benzer çalışmalar incelenerek ilgili tema altına yerleştirilip yorumlanmıştır. Öğretmen adaylarının özel eğitime ilişkin ürettikleri metaforlar ve bu metaforlara ilişkin öne sürülen gerekçeler incelenerek toplam da 5 ayrı kategori oluşturulmuştur.

Geçerlik ve Güvenirliği Sağlama Aşaması: Çalışmanın geçerlik, güvenirlik ve objektiflik ölçütlerini karşılamasına dikkat edilmiştir. Araştırmanın iç geçerliğini arttırmak için anket formu geliştirilirken ilgili alan yazın ayrıntılı bir biçimde incelenmiş ve konu ile ilgili bir kavramsal bir çerçeve oluşturulmuştur. Araştırmanın diş geçerliğini arttırmak için çalışma grubunda yer alan katılımcılara ilişkin detaylı bilgi sunulmuştur (Miles, Huberman ve Saldana, 2014). Araştırmanın iç güvenirliğini arttırmak için araştırma soruları açıkça ifade edilmiştir ve araştırma deseni bu sorulara yanıt verebilecek şekilde seçilmiştir. Araştırmada dış güvenirliği (objektifliği) sağlamak için süreç boyunca yapılanlar ayrıntılı bir biçimde açıklanmıştır. Veri toplama aracı, verinin nasıl toplandığı ve verilerin nasıl analiz edildiği hakkında bilgiler ve katılımclardan elde edilen doğrudan alıntılara yer verilmiştir (Wiersma, 1995). Kodlayıcı güvenirliği için Miles ve Huberman (2014)'ın önerdiği Uzlaşma Yüzdesi = Görüş Birliği / (Görüş Birliği + Görüş Ayrılıği) * 100 formülü kullanılmıştır. Bu formül kullanılarak hesaplanan güvenirlik yüzdesi \% 93 olarak belirlenmiştir. Bu yüzde güvenirlik katsayısına dönüştürüldüğünde güvenirlik katsayısı .93 olarak hesaplanmıştır. MilesHuberman güvenirlik formülü değerinin .70'den yukarı olması durumunda kodlamaların güvenilir olduğu kabul edildiğinden, bu çalışma için yapılan kodlamaların yüksek düzeyde güvenilir olduğu söylenebilir.

Verileri Bilgisayar Ortamına Aktarma Aşaması: Öğretmen adayları tarafından üretilen metaforlar ve bu metaforların yer aldığı kavramsal kategoriler belirlendikten sonra, her bir kategori altındaki formlar sırasıyla ÖA1, ÖA2, ÖA2 .................̈̈A85 şeklinde numaralandırılarak bilgisayar ortamina aktarılmıştır. 


\section{Bulgular ve Yorum}

Bu araştırma kapsamında İngilizce, Türkçe, Sosyal Bilgiler ve Resim-iş öğretmenliği bölümü son sınıf öğretmen adaylarının özel eğitim kavramına yönelik toplam 81 metafor ürettikleri görülmektedir. Söz konusu metaforlar araştırmacılar tarafından "İhtiyaç olarak özel eğitim" "Eğitimde fırsat eşitliğini sağlama aracı olarak özel eğitim", "Özel ilgi ve yardım aracı olarak özel eğitim", "Koşulsuz kabul sağlama aracı olarak özel eğitim" ve "Farklılık" olarak özel eğitim" olmak üzere toplam 5 tema altında gruplanmıştır. Araştırma kapsamında öğretmen adaylarının belirlenen temalara ilişkin ürettikleri metaforların dağılımı Tablo 2. de gösterilmektedir.

Tablo 2. Öğretmen adaylarnın özel eğitime ilişkin metaforlarnın temalara göre dă̆ıll-

\begin{tabular}{lll}
$\boldsymbol{m} \boldsymbol{\imath}$ & $\mathbf{N}$ & $\mathbf{\%}$ \\
\hline Temalar & 14 & 16,5 \\
\hline İhtiyaç olarak özel eğitim & 32 & 37,6 \\
\hline Eğitimde fırsat eşitliği sağlama aracı olarak özel eğitim & 12 & 14,1 \\
\hline Özel ilgi ve yardım aracı olarak özel eğitim & 21 & 24,7 \\
\hline Koşulsuz kabul sağlama aracı olarak özel eğitim & 6 & 7,1 \\
\hline Farklılık olarak özel eğitim & 85 & 100,0 \\
\hline Toplam &
\end{tabular}

Öğretmen adaylarının özel eğitim kavramına ilişkin ürettikleri metaforların temalara göre dağılımına bakıldığında en fazla metaforun $(n=32)$ "eğitimde fırsat eşitliği sağlama aracı olarak özel eğitim" teması altında toplandığı, en az ise (n=6) "farklılık olarak özel eğitim" teması altında toplandığı görülmektedir.

\section{Tema 1. İhtiyaç Olarak Özel Ĕ̆itim}

Bu tema altında toplam 14 öğretmen adayı 7 metafor üretmiştir. Üretilen metaforlar içerik olarak incelendiğinde, öğretmen adaylarının özel eğitimi temel bir ihtiyaç olarak olumlu bir şekilde algıladıkları belirlenmiştir. Öğretmen adayları tarafından bu tema altında üretilen metafor ve her bir metaforun kaç defa kullanıldığı Tablo 3. de verilmiştir. 
Tablo 3. İhtiyaç olarak özel eğitim teması altında oluşturulan metaforlar

\begin{tabular}{lll}
\hline Tema 1 & Metafor & F \\
\hline & Su & 4 \\
& İhtiyaç & 5 \\
& Doğadaki farklı bir çiçek & 1 \\
\multirow{3}{*}{ İhtiyaç olarak özel eğitim } & Fidan & 1 \\
& Ekmek & 1 \\
& Trafik ve ilk yardım & 1 \\
& Toplumsal bir görev & 1 \\
& Toplam & 14 \\
\hline
\end{tabular}

İhtiyaç olarak özel eğitim teması altında oluşturulan metaforlara bakıldığında son sınıf öğretmen adaylarının özel eğitimi en çok ihtiyaç (5), su (4), ekmek (1) ve fidan (1) gibi insan yaşamı için önemli ve gerekli görülen unsurlara benzettikleri gözlenmektedir. Bu tema altındaki metaforların ortak özelliklerine bakıldığında özel eğitim dersinin insan hayatı için olmazsa olmazı olarak görüldüğü, insan yaşamının devam edebilmesi için gerekli görülen temel ihtiyaçlar kadar önemli görüldüğü anlaşılmaktadır. İhtiyaç olarak özel eğitim teması altında oluşturulan metafor ifadelerinden bazıları şu şekildedir:

- Nasil ki insanlar hayatlarım idame etmek için en temel ihtiyaç olan suya gereksinim duyarlar, özel gereksinimi olan bireyler de özel eğitime ihtiyaç duyarlar. Günümüz toplumunda maalesef ki engelli olan ya da normalden farkl kişilere iyi bakllmıyor ve bu sırada özel eğitim deoreye girmesi gerekiyor....[ÖA2].

- Nasil ki insan su olmadan yaşayamaz, özel eğitim de olmazsa noksanliklar tamamlanamaz...[ÖA3].

- ...insanı hayatta tutan en temel besinimiz ekmek olduğu gibi hayatta da var olmamızı, insan değerlerine tabi olabilmemiz için eğitime ihtiyacımız vardır. Bir eksiklik nedeniyle bu değerden mahrum birakılmamal, özel eğitim ile topluma kazandirllmalı...[ÖA9].

- Özel eğitim yalnizca öğretmen adaylarn için değil toplumun her kesimine verilmesi gereken bir eğitim olduğu için bence zorunluluktur... [ÖA13].

- Özel eğitim, özel durumu olan bireylerin ihtiyaçlarına yardımda bulunmaktır. Özel eğitimin bir ülkede gelişimi o ülkedeki özel eğitime muhtaç olan bireylerin gelişimi için belirleyici bir rol oynar...[ÖA14]. 


\section{Tema 2. Eğitimde Fursat Eşitliği Sağlama Aracı Olarak Özel Eğitim}

Bu tema altında toplam 32 öğretmen adayı 30 metafor üretmiştir. Üretilen metaforlar içerik olarak incelendiğinde, öğretmen adaylarının özel eğitimi eğitimde fırsat eşitliği sağlama aracı olarak algıladıkları belirlenmiştir. Öğretmen adayları tarafından bu tema altında üretilen metafor ve her bir metaforun kaç defa kullanıldığı Tablo 4. de verilmiştir.

Tablo 4. Eğitimde fırsat eşitliği sağlama aracı olarak özel eğitim teması altında oluşturulan metaforlar

\begin{tabular}{lllll}
\hline Tema 2 & Metafor & N & Metafor & f \\
\hline & Anne-baba & 1 & Bir tür ayna & 1 \\
& Anne-baba şefkati & 1 & Futbol & 1 \\
& Tuvale resim çizme & 1 & Eşitlik & 1 \\
& Kişinin sosyalleşmesi & 1 & Şans & 1 \\
& Heykel sanatı & 1 & Hareketsiz madde & 1 \\
& Kişiye özel eğitim & 1 & Meyve veren bir ağaç & 2 \\
Eğitimde fırsat eşitliği & Biyoloji dersi & 1 & Arı & 1 \\
sağlama aracı olarak & Farkındalık & 2 & Fidan & 1 \\
özel eğitim & Ay & 1 & Eğitimin temel taşlarına & 1 \\
& Işı & 1 & Yeni yeşeren bir çiçek & 1 \\
& Umut & 1 & Hayat kurtarmak & 1 \\
& Zor & 1 & Bir ağacın gelişimi & 1 \\
& Program & 1 & Yeniden yapılandırma & 1 \\
& Müzik & 1 & Özel ilgi & 1 \\
& Yol haritası & 1 & Bir tür ayna & 1 \\
& Toplam & 32 & & \\
\hline
\end{tabular}

Eğitimde fırsat eşitliği sağlama aracı olarak özel eğitim teması altında oluşturulan metaforlara bakıldığında son sınıf öğretmen adaylarının özel eğitimi en çok farkındalık (2) ve meyve veren bir ağaca (2) benzettikleri görülmektedir. Bunun yanı sıra öğretmen adayları özel eğitime ilişkin annebaba (1), 1şık (1), umut (1), şans (1), eşitlik (1) ve hayat kurtarma (1) şeklinde metaforlar da kullandıkları görülmektedir. Üretilen metaforlar incelendiğinde öğretmen adaylarının özel eğitimi özel gereksinimli çocukların yetenek ve becerileri dâhilinde eğitime tabi tutulmasına yardımcı olarak eğitimde firsat eşitliği sağlamaya katkıda bulunduğu görüşüne sahip oldukları anlaşılmaktadır. Eğitimde fırsat eşitliği sağlama aracı olarak özel eğitim olarak özel eğitim teması altında oluşturulan metafor ifadelerinden bazıları şu şekildedir: 
- Özel eğitime gereksinimi olan çocuklara en iyi şekilde ancak bilimsel olarak yaklaşılıp yardımcı olunabilir. Tabi bu bilimsel yaklaşımların yanı sira annebaba şefkati, iyi niyet ve üstün çaba tamamlayabilir...[ÖA16].

- Psikolojik ve kalttımsal olarak sikintısi olan bireylerin normal olarak aileden göreceği eğitim çok yetersiz kalmaktadır. Dolayısıyla kişinin sosyalleşmesi veya kültür açısından yetersiz olmasına sebebiyet vermektedir. Özel eğitim bu açıdan öğrencilerin sosyalleşmesini ve var olan yeteneklerinin inkişaf edilmesine büyük katkı sağlamaktadır...[ÖA19].

- İnsan sağhığım temel alan özel eğitim dersi sağllk ve yaşam adına gelişimi sağlar. Karşılaştığımız kişilerin özel durumlarım anlamamızı, bu özel durumlar karşısında bilinçli davranmamızı sağlar...[ÖA22].

- Özel eğitime muhtaç çocukların hayatına bir nebze olsun ışık saçar. O çocukları anlamayan insanlar çevrelerinde oldukça hayatları gece gibi kararır. Oysa özel eğitim sayesinde onlara özel eğitim verecek olan kişiler sayesinde ufakta olsa hayatlarında birşeyler değgişir. O karanlı̆̆ı biraz da olsa özel eğitim bir ay gibi aydinlatır...[ÖA24].

- Özel eğitime ihtiyaç duyan bireyler içinde bulundukları durumdan dolayı normal bireylerden daha geridedirler. Illerleyişleri ve gelişimleri de normal bireylere oranla daha yavaştır. Bu açıdan normal bireyler aydınlık birgeleceğe ilerlerken, özel eğitim "ışık" rolü oynayarak özel eğitime ihtiyaç duyan öğrenciler hayata hazzrlanmaktadır...[ÖA25].

- Hasta olan çocuklarm nasıl eğitim alacaklarn, onlarla nasıl ilgilenileceğine dair bilgi veren bir yol haritasıdır...[ÖA30].

\section{Tema 3. Özel İlgi ve Yardım Sağlama Aracı Olarak Özel Ĕ̆itim}

Bu tema altında toplam 12 öğretmen adayı 10 metafor üretmiştir. Üretilen metaforlar içerik olarak incelendiğinde, öğretmen adaylarının özel eğitimi özel ilgi ve yardım aracı olarak algıladıkları belirlenmiştir. Öğretmen adayları tarafından bu tema altında üretilen metafor ve her bir metaforun kaç defa kullanıldığı Tablo 5. de verilmiştir. 
Tablo 5. Özel ilgi ve yardım aracı olarak özel eğitim teması altında oluşturulan metaforlar

\begin{tabular}{lll}
\hline Tema 3 & Metafor & F \\
\hline & Yüzüklerin efendisi serisi & 1 \\
& Çiçek & 2 \\
& Nazik bir bebek & 1 \\
Özel ilgi ve yardım aracı & Ağaç & 1 \\
Olarak özel eğitim & Bakıma muhtaç bahçe & 2 \\
& Dalından kopmuş gül & 1 \\
& Bir bitki & 1 \\
& Canlı & 1 \\
& Toprak & 1 \\
& Kızılay & 1 \\
& Toplam & 12 \\
\hline
\end{tabular}

Özel ilgi ve yardım sağlama aracı olarak özel eğitim teması altında oluşturulan metaforlara bakıldığında son sınıf öğretmen adaylarının özel eğitimi en çok bakıma muhtaç bahçe (2) ve çiçeğe (2) benzettikleri, yine ağaç (1), dalından koparılmış gül (1), toprak (1), bir bitki (1) gibi metaforlar kullandıkları görülmektedir. Üretilen metaforlar incelendiğinde öğretmen adaylarının özel eğitimin, özel gereksinimli bireylere yönelik özel ilgi ve yardım sağlamaya dönük bilgiler sağladığı görüşüne sahip oldukları anlaşılmaktadır. Özel ilgi ve yardım sağlama aracı olarak özel eğitim teması altında oluşturulan metafor ifadelerinden bazıları şu şekildedir:

- Her zaman yeri özeldir. İlgiyle izlenmeli ve takip edilmelidir. Üstünde uğraş verilmelidir...[ÖA47].

- Bakıma, ilgiye, önemsenmeye ve kazanilp yaşatılmaya muhtaçtır. Diğerlerine göre farklı olmak ya da zayıf olmak onlarm suçu değildir. Normalden biraz daha özenmek gerekir ki en güzel şekilde onlar da açılabilsin...[ÖA48].

- Bebekler sürekli ilgi, şefkat ister özel eğitime muhtaç çocuklar da büyük bir sabır ve çaba ister...[ÖA49].

- Her bahçede özel gereksinimlere ihtiyaç duyan eksikliklerini özel bir ilgiyle tamamlayan çiçekler vardır. Çocuklarda bu şekildedir...[ÖA51].

- Canlı bir varlık düşünün. Bu varlık çeoresinden gelen tepkilerden çokça etkilenir. Ĕ̆ger biz bu canl varlığa olumlu davranışlarda bulunursak kendisinden ayn olumlu davranışları görürüz. Bunun için özel eŏitime ihtiyaç duyan bir bireye ona uygun bir program dâhilinde ders verilirse biz bu bireyi topluma yararl bir hale dönüştürebiliriz. Aksini sergilersek, onu görmez- 
den gelirsek, onu umursamazsak o tıpkı canlı bir çiçek gibi bir kenarda solup gidecektir...[ÖA54].

- Toprak ekilmediği ve sulanmadığı zaman herhangi bir verim elde edemezsiniz. Özel eğitime gereksinim duyan bireylerde de topră̆ın ekilip, sulanıp biçildiği gibi bakıma ihtiyaçları vardır. Bu bakım, sevgi, bilgi, tecrübe, ihtiyaç karşılama, umut vb.dir...[ÖA56].

\section{Tema 4. Koşulsuz Kabul Sağlama Aracı Olarak Özel Eğitim}

Bu tema altında toplam 21 öğretmen adayı 20 metafor üretmiştir. Üretilen metaforlar içerik olarak incelendiğinde, öğretmen adaylarının özel eğitimi koşulsuz kabul sağlama aracı olarak algıladıkları belirlenmiştir. Öğretmen adayları tarafından bu tema altında üretilen metafor ve her bir metaforun kaç defa kullanıldığı Tablo 6. da verilmiştir.

Tablo 6. Koşulsuz kabul sağlama aracı olarak özel eğitim teması altında oluşturulan metaforlar

\begin{tabular}{lllll}
\hline Tema 4 & Metafor & f & Metafor & f \\
\hline & Bizler & 1 & Normal birey & 1 \\
& Tutku & 1 & Anne & 1 \\
& Işsk & 1 & Aile & 1 \\
Koşulsuz & Sempati & 1 & Sevgi & 1 \\
kabul aracı & Beyaz bir tablo & 1 & Dişardan gözlenen bir tablo & 1 \\
olarak özel & Farkındalık yaratma & 2 & Kapalı bir kutu & 1 \\
eğitim & Taşın içinden filizlenen bir bitki & 1 & Kutsallık & 1 \\
& Sanatsal dokunuş & 1 & Melek & 1 \\
& Kelebek & 1 & Cennet bekçileri & 1 \\
& Direniş & 1 & Piyano & 1 \\
& Toplam & 21 & & \\
\hline
\end{tabular}

Koşulsuz kabul sağlama aracı olarak özel eğitim teması altında oluşturulan metaforlara bakıldığında son sınıf öğretmen adaylarının özel eğitimi en çok farkındalık yaratmaya (2) benzettikleri yine anne (1), aile (1), sevgi (1), sanatsal dokunuş (1), kutsallık (1) gibi metaforlar kullandıkları görülmektedir. Üretilen metaforlar incelendiğinde öğretmen adaylarının özel eğitimin, özel gereksinimli bireylere yönelik koşulsuz kabul ve saygı sağlamaya dönük bilgiler sağladığı görüşüne sahip oldukları anlaşılmaktadır. Koşulsuz kabul sağlama aracı olarak özel eğitim teması altında oluşturulan metafor ifadelerinden bazıları şu şekildedir: 
- Özel eğitime gereksinimi olan bireyler öncelikle saygıya, hoşgörüye ve dışlanmamaya, toplumda kabul görülmeye ihtiyaç duyarlar. Bizler de geleceğin birer öğretmen adayı olarak özel eğitim öğrencilerine daha fazla önem vermeli, onlarla ilgilenmeliyiz. Ama bunu yaparken normal öğrencilerden ayrı tutarak değil onlarla birlikte aynı ortamda, onları incitmeden eksikliklerini kapatmaya çalışmahıız. Bunun için de dikkatli hareket etmeliyiz...[ÖA59].

- Bedensel, zihinsel, fiziksel yetersizliği olan çocuklar özeldir. Bu çocuklar dünyaya sunulmuş farklı tatlardır, gizemli renklerdir. Bu çocukları anlamak, anlamlandırmak, hayatlarına müdahil olabilmek, herkesten farkl dünyalarmı ufak bir pencereden görebilmek sanatsal bir dokunuş gibidir...[ÖA66].

- Ne kadar hassas ve dikkatli davramirsaniz/yaklaşırsanız o kadar güzel olur, ilerler ve yaşamaya devam eder. Sert etkileşimde ise parçalanır, yok olur ve ölür...[ÖA67].

- Özel eğitim, özel eğitime muhtaç bireylerin toplumda normal sayılan bireyler tarafindan kabul görme mücadelesine yardımcı olur. Özel eğitime muhtaç bireylerin var olma mücadelesi için yol göstericidir. Bu zorlu süreçte onlarm direnişine katkı sağlar. Yani özel gereksinimli bireylerin direniş parçasıdır özel eğitim...[ÖA68]

- Özel eğitim gereksinimi olan bireyleri, normal bireylerden ayırmadan, ötekileştirmeden hoşgörü, saygı ve sevgiyle karşılamak önemli noktalardan biridir. Toplumda kabul görmeleri gerekir farkh bir durumda ya d özellikte olduğunu onlara hissettirmemeliyiz. Onları da bizler gibi duyguları olduğunu unutmamalı ona göre davranmal ve ötekileştirmemeliyiz...[ÖA69].

- Özel eğitime muhtaç bireyler her zaman toplum içinde kabul görmeyi bekler. Bunu ayn zamanda okul ortamlarında, eğitim görecekleri yerden de isterler. Öğretmenlerinin, arkadaşlarının da tıpkı aile gibi onları desteklemesini isterler...[ÖA72].

\section{Tema 5. Farklılık Olarak Özel Eğitim}

Bu tema altında toplam 6 öğretmen adayı 6 metafor üretmiştir. Üretilen metaforlar içerik olarak incelendiğinde, öğretmen adaylarının özel eğitimi bir farklılık olarak algıladıkları belirlenmiştir. Öğretmen adayları tarafından bu tema altında üretilen metafor ve her bir metaforun kaç defa kullanıldığı Tablo 7. de verilmiştir. 
Tablo 7. Farklılık olarak özel eğitim teması altında oluşturulan metaforlar

\begin{tabular}{lll}
\hline Tema 5 & Metafor & f \\
\hline & Sosyal aktivite & 1 \\
& Tamamlanmamış ev & 1 \\
Farklılık olarak özel eğitim & Beş parmak & 1 \\
& Dört yapraklı yonca & 1 \\
& Bir resim & 1 \\
& Gökkuşağı & 1 \\
& Toplam & 6 \\
\hline
\end{tabular}

Farklılık olaraközel eğitim teması altında oluşturulan metaforlara bakıldığında son sınıf öğretmen adaylarının özel eğitimi sosyal aktivite (1), bir resim (1), gökkuşağı (1), tamamlanmamış ev (1), dört yapraklı yonca (1), beş parmak (1) gibi metaforlar kullanarak özel gereksinimli bireylerin farklı oldukları ve özel eğitimin ise bu farklılıklara yönelik bir farkındalık oluşturmaya yönelik bilgiler sağladığı görüşüne sahip oldukları anlaşılmaktadır. Farklılık olarak özel eğitim teması altında oluşturulan metafor ifadelerinden bazıları şu şekildedir:

- Öğrenciler kendi farklılkların görürler. Özel olduklarmı hissederler, özgür olurlar...[ÖA80].

- Farkl farklı hastaliklar ve sorunlara rağmen tedavi sürecinde bile hep beraber eğlenip öğrenebiliyorsun hatta mutluluğu beraber yaşıyorsun...[ÖA82].

- Aslında hayatımızda vardır ama bulunması nadirdir. Çok sık görülmez. Görüldüğü zaman bizim için özeldir, tektir, biriciktir, farklilktır...[ÖA83].

- Bir resimde farkl renkler vardır. Renkler nasıl bir arada uyumlu ise özel eğitim de öyledir. Onlar farkh ama hayat farklılklarla güzeldir...[ÖA84].

- Özel eğitim farklhlikları bir araya getirir...[ÖA85].

\section{Tartışma}

$\mathrm{Bu}$ araştırma öğretmen adaylarının, özel eğitime ilişkin görüşlerini metaforlar aracılığıyla ortaya çıkarmak için gerçekleştirilmiştir. Araştırmada özel eğitim ile ilgili toplam 85 metafor elde edilmiştir. Katılımcllar tarafından üretilen bu metaforlar "ihtiyaç olarak özel eğitim", "eğitimde firsat eşittiğini să̆lama aracı olarak özel eğitim", "özel ilgi ve yardım aracı olarak özel eğitim”, "koşulsuz kabul sağlama aracı olarak özel eğitim" ve "farklllk olarak özel eğitim" olmak üzere 5 kategoride toplanmıştır. 
Öğretmen adayları tarafından en fazla metaforun üretildiği kategoriler eğitimde fursat eşitliği ve koşulsuz kabul kategorileridir. Toplamda 5 kategori altında yer alan 85 adet metafordan 43 tanesi bu iki kategoride yer almaktadır. Ayrıca katılımcılar tarafından en çok üretilen "ihtiyaç $(n=5)$ " metaforu ise ihtiyaç olarak özel eğitim kategorisinde yer almaktadır. Bunun d1şında 'su $(n=4)$, meyve veren ağaç $(n=2)$, çiçek $(n=2)$, farkındalık $(n=4)$ ve bakıma muhtaç bahçe $(\mathrm{n}=2)$ üretilen diğer en sık metaforlardır. Araştırma verileri doğrultusunda öğretmen adaylarının 'özel eğitim' kavramına yönelik olumsuz bir metafor üretmedikleri belirlenmiştir. Araştırmanın bu sonucu Uçuş (2016) tarafından sınıf ve okul öncesi öğretmen adaylarının "Özel Eğitim'e ilişkin genel olarak algılarının olumlu yönde olduğu belirlenen araştırmanın bulguları ile benzerlik taşımaktadır. Ayrıca elde edilen metaforlar Uçuş (2016) tarafından yapılan araştırmanın sonuçları ile karşılaştırıldığında, "çiçek, meyve veren ağaç, su, anne, ağaç" metaforların ortak olduğu görülmüş̧ür.

Araştırma sonucunda en fazla metaforun üretildiği eğitimde firsat eşitliği kategorisinde öğretmen adayları normal gelişim gösteren öğrenciler gibi özel eğitim gerektiren her bireyin de eğitim haklarının olduğunu, gerekli sabır ve sevgi ile bu çocukların gelişimlerinin en üst düzeye çıkabileceğini belirtmişlerdir. Araştırmanın verileri öğretmen adaylarının özel eğitim dersini almaya başladıktan iki hafta sonra toplanmıştır. Özel eğitim dersinin ilk iki ünitesinde özel eğitim ile ilgili genel kavramlar ve özel eğitimin neden gerekli olduğu gibi konular anlatılmaktadır. Ayrıca özel gereksinimli her bireyin eğitim görme haklarının yasalar ile güvence altına alındığı da "özel eğitimde yasal düzenlemeler" başlı̆̆ı altında bu dersin ilk konuları arasında ele alınmaktadır. Öğretmen adaylarının görev başladıktan sonraki tutumları üzerinde öğrenim sürelerince aldıkları dersler ve bilgilendirmelerin etkili olabileceği bildirilmektedir (Kayhan, Şengül ve Piştav-Akmeşe, 2012). Dolayısıyla farklı öğretmenlik bölümlerinde okuyan aday öğretmenlerin eğitimde fırsat eşitliğine yönelik daha çok metafor üretmelerinin nedeninin özel eğitim dersinin içeriğinden kaynaklandığı düşünülmektedir.

Öğretmen adaylarının ikinci olarak en fazla metafor ürettikleri tema " $k o$ şulsuz kabul sağlama aracı olarak özel eğitim" temasıdır. Bu kategoride öğretmen adayları özel gereksinimli bireylerin normal gelişim gösteren çocuklardan bir farkı olmadıklarını belirtmişler ve onları ötekileştirmeden, hoşgörüyle sayg1 ve sevgiyle toplumda kabul etmenin önemimden bahsetmişler- 
dir. Araştırmanın bu sonucu İlgar (2017) tarafından gerçekleştirilen öğretmen adaylarının özel gereksinimli öğrencilerle ilgili farkındalıklarının incelendiği çalışmanın bulguları ile benzerlik taşımaktadır. Bu araştırmada da öğretmen adayları tüm öğrencilere eşit davranılması gerekliliğini ve özel gereksinimli çocuk ile normal gelişlim çocuklar arasında ayrım yapılmaması gerektiğini ifade etmişlerdir.

Çalışmada öğretmen adayları tarafından üçüncü ve dördüncü sırada "ihtiyaç olarak özel eğitim ve özel ilgi ve yardım aracı olarak özel eğitim" temalarında metafor üretilmiştir. İhtiyaç olarak özel eğitim temasında, özel eğitimin özel gereksinimli çocukların hayatındaki öneminden bu çocukların özel eğitim almazsa ileride yaşayabilecekleri sorunlardan bahsedilmiştir. Özel gereksinimli çocukların normal gelişim gösteren çocuklara göre daha çok ilgi ve desteğe ihtiyacı olduğu da bu tema altında yer almıştır. İhtiyaç temasında öğretmen adayları özel gereksinimli bireylerin "özel eğitime" temel gereksinimler kadar ihtiyaç duyduklarından bahsetmişlerdir. Özel ilgi ve yardım aracı olarak özel eğitim temasında ise özel gereksinimli bireylerin bakıma, ilgiye, önemsenmeye ve yardıma ihtiyaçları oldukların belirtmişlerdir. Öğretmen adaylarının en az metafor ürettikleri tema ise "farklılık olarak özel eğitim" temasıdır. Bu temada özel gereksinimli her bireyin farklı özellik ve ihtiyaçları olduğundan bahsedilmiştir.

Öğretmen adaylarının görüşleri genel olarak incelendiğinde daha çok özel eğitimin genel amacı ve özel gereksinimli çocukların özellikleri üzerine metafor ürettikleri belirlenmiştir. Öğretmen adayların kaynaştırma eğitimine çok değinmedikleri ve özel gereksinimli çocukların eğitim ihtiyaçlarından ise daha az bahsettikleri görülmüştür. Araştırmanın bu sonucunun öğretmen adaylarının kaynaştırma ile ilgili yeterli bilgi sahibi olmamasından kaynaklandığı düşünülmektedir. Türkiye'de 2006 yılında Yükseköğretim Kurulu tarafından öğretmen yetiştirme programları incelendiğinde öğretmen adaylarının iki saatlik zorunlu özel eğitim dersi aldıkları görülmektedir. Buna karşın, kaynaştırma dersi seçmeli olmak ile beraber sadece sınıf ve özel eğitim öğretmenliği lisans programlarında zorunludur. Benzer şekilde yapılan araştırmalarda da öğretmenlerin kaynaştırma hakkında bilgi sahibi olmadan mezun oldukları belirtilmektedir (Orel, Töret ve Zerey; 2004; Sucuoğlu, Bakkaloğlu, İşcen Karasu, Demir ve Akalın, 2014). Dolay1sıyla öğretmelerin adaylarının kaynaştırmaya yönelik bilgileri ileride mesleki hayatlarında kaynaştırma uygulamalarını etkili bir şekilde gerçekleş- 
tirmelerinde ve özel gereksinimli çocukların sınıfın daima bir üyesi olduklarını kabul etmede önemlidir.

Öğretmen adaylarının özel eğitim dersinde kazandıkları bilgileri kullanabilecekleri en önemli ortam, öğretmenlik hayatlarına başladıklarında kaynaştırma uygulamalarının yürütüldüŭü sınıflar olacaktır. Kaynaştırmanın başarısı, eğitimin her kademesinde görev yapan öğretmenlerin kaynaştırma eğitimi hakkında bilgi sahibi olmasından etkilenmektedir (Kayhan ve ark., 2012). Dolayısıyla öğretmen adaylarının özel gereksinimli öğrenciler ile ilgili aldıkları tek ders olan "özel eğitim dersinin" içeriğinin kaynaştırma uygulamalarına daha çok yer verilecek şekilde geliştirilmesi önemli bir adım olarak görülmektedir. Türkiye' de yapılan çalışmalarda öğretmen adaylarının kaynaştırma eğitimi hakkında bilgi, beceri ve deneyimlerin sınırlı olması nedeniyle; sınıflarında özel gereksinimli olan çocukların ihtiyaçlarını karşılamada etkili olmadıkları belirtilmiştir (Batu, 2010; Sucuoğlu ve ark., 2014). Lisans eğitiminde kaynaştırma ile ilgili ders alan öğretmen adaylarının ise mesleki yaşantılarında kaynaştırmaya yönelik tutumlarının daha olumlu olduğu bildirilmiştir (Orel, Töret ve Zerey; 2004). Dolayısıyla kaynaştırmaya yönelik lisans döneminde herhangi bir ders almayan öğretmenlerin mesleki yaşantılarında özel gereksinimli öğrencilere yönelik bireyselleştirilmiş eğitim programları hazırlamada, öğretimi bireyselleştirmede, sınıf yönetimini üstlenmede ve sorunlu davranışlarla başa çıkmada problem yaşamaları kaçınılmazdır (Gök ve Erbaş, 2011; Saraç ve Çolak, 2012; Varlıer ve Vuran, 2006). Alan yazında etkili kaynaştırma uygulamalarının önündeki en büyük engelin öğretmenler ve öğretmen adaylarının kaynaştırma eğitimine yönelik bilgi eksikliğinden ortaya çıkan olumsuz tutumlar olduğu dile getirilmektedir (Gözün ve Yıkmış, 2004; Sarı, 2002; Şahbaz ve Kalay, 2010). Tüm bunlar göz önüne alındığında, özel eğitim dersinin YÖK tarafından yapılan yeni düzenleme ile özel eğitim ve kaynaştırma olarak geliştirilmesinin önemli olmasının yanı sıra "kaynaştırma uygulamaları" dersinin ayrı bir ders olarak uygulamalı şekilde verilmesi ve bu dersin farklı anabilim dallarında zorunlu ders olarak yaygınlaştırılması önemli görülmektedir.

Son olarak bu araştırmanın göz önüne alınması gereken bazı sınırlılıkları bulunmaktadır. Bu araştırma Dicle Üniversitesinde eğitim görmekte olan İngilizce Öğretmenliği, Sosyal Bilgiler Öğretmenliği, Resim-Iş̧ Öğretmenliği ve Türkçe Öğretmenliği bölümlerinde 4. Sınıfta öğrenimine devam eden 85 öğretmen adayı ile gerçekleştirilmiştir. Bulguların genellenebilirliğinin arttı- 
rılması amacıyla farklı eğitim fakültelerinin diğer anabilim dallarında öğretmen adaylarının özel eğitim algıları metafor yoluyla incelenebilir. Ayrıca öğretmen adaylarının özel eğitime yönelik algıların özel eğitim dersi aldıktan sonra değişip değişmediği araştırılabilir. 
EXTENDED ABSTRACT

\title{
Prospective Teachers' Metaphoric Perceptions of Special Education
}

\author{
Özlem Altındağ Kumaş - Sedef Süer \\ Dicle University
}

Inclusive education has been applied in Turkey since the year of 1980. With the introduction of inclusive education, the rate of educating the children with special needs in classrooms of students with normal development has been increasing day by day (Ministry of National Education [MEB], 2015). After inclusive education became a legal right for students with special needs, one or more students with special needs can be educated in almost all schools at every grade level in our country (Akalın, 2015). Therefore teachers who can be assigned at every grade level need to have knowledge about special education / inclusive education before strating the profession in order to be able to implement effectively inclusive practices and meet the needs of students with special needs (Vuran, 2013).

It is important that teachers who are primarily responsible for the effective implementation of inclusive education develop positive perceptions and attitudes towards special education before starting their career. When the literature is examined, there are studies examining the attitudes and perceptions of pre-service teachers about special education (Atay, 1995; Gökdere, 2012; Fırat Durdukoca, 2015; Özbaba, 2000; Soyyiğit, 2013; Yazıcıŏlu, 2019), however Anyqualitative study that address pre-service teachers' perceptions about private education in a more free, creative and sophisticated way has not been found yet. Thereby, the metaphors which reveal more effectively the pre-service teachers 'perceptions about special education by using less words (Girmen, 2007), are thought to provide clearer information about the pre-service teachers' perceptions about special education. Therefore, the aim of this research is to examine the pre-service teachers' perceptions of special education with the help of metaphors.

This study examining the prospective teachers' metaphoric perceptions about special education was conducted with the participation of 85 prospec- 
tive teachers in 2019-2020 academic year. Senior students studying in English teaching, Turkish teaching, Social Studies and Art Teaching programs of an education faculty were included in the study. The required data for the study were obtained by asking the prospective teachers filling a survey form containing the statement of "Special education looks like a/an...................because.................". The obtained data were analyzed and interpreted by using content analysis method.

Findings showed that prospective teachers produced 85 metaphors categorized under 5 themes: "Special education as a need", "Special education as a means of ensuring equal opportunities in education", "Special education as a special interest and aid tool", "Special education as a means of providing general acceptance" and "Special education as a differences". When the opinions of the pre-service teachers were examined in general, the produced metaphors were determined to be mostly on the general purpose of special education and the characteristics of children with special needs. It was observed that pre-service teachers did not touch the inclusive education and talked less about the educational needs of children with special needs. This result is thought to due to the lack of sufficient knowledge of preservive teachers about inclusive education. The teacher training programs, which were developed by the Higher Education Council in Turkey in 2006, offered only two hour elective courses for special education. What is more, inclusive education course was offered as an optional for most of branches except from undergraduate programs of classroom and special education which offered elective inclusive education course for their students. The related studies also showed that teachers graduated without knowledge of inclusive education (Orel, Töret and Zerey; 2004; Sucuoğlu, Bakkaloğlu, İşcen Karasu, Demir and Akalın, 2014). Therefore, the preservice teachers' knowledge about inclusive education is important to carry out inclusive educational practices effectively in their professional life and to accept that children with special needs are always members of their classrooms.

The most important context for pre-service teachers to use the knowledge gained in the special education course will be the classrooms where inclusive practices are carried out when they start their profession. The success of inclusive education is based on teachers' knowledge about inclusive education, who will be working at all levels of educational institutions (Kayhan et al., 2012). Therefore, it is seen as an important step to enrich the content of 
the "special education course" with more knowledge and practices related to inclusive education. The fact that the studies conducted in Turkey denoted limited skills and experience of preservice teachers about inclusive education; the teachers stated that they are not effective in meeting the needs of children with special needs in their classrooms (Batu, 2010; Sucuoğlu et al., 2014;). Pre-service teachers taking undergraduate courses in their undergraduate training were reported to have more positive attitudes towards inclusion in their professional lives (Orel, Töret and Zerey; 2004). Therefore, it is inevitable that the teachers having not taken any courses related to inclusive education in their undergraduate training process have problems in preparing individualized education programs for students with special needs, individualizing the teaching, undertaking classroom management and dealing with problematic behaviors (Gök and Erbaş, 2011; Saraç and Çolak, 2012; Varlier and Vuran, 2006). It is stated that the biggest obstacle to effective inclusion practices in the literature is negative attitudes, which arise from the teachers' and prospective teachers' insufficient knowledge about inclusive education (Gözün and Yıkmış, 2004; Sarl, 2002; Şahbaz and Kalay, 2010). Considering all these, it is important that special education course is reformed as "special education and inclusion course" with the new regulation made by Higher Education Council (YOK) in 2018. Besides inclusive education course needs to be seperated from the special education course and offered as an elective course for different branch of teaching.

This research has some limitations to consider. This study was conducted with 85 senior students studying in English Language Teaching, Turkish Language Teaching, Social Studies and Art Teaching programs of an education faculty in Dicle University. In order to increase the generalizability of the findings, preservice teachers' perceptions of special education in other departments of different education faculties can be examined through metaphors. In addition, whether the perceptions of preservice teachers towards special education change after having taken special education course can also be investigated.

\section{Kaynakça / References}

Akalın, S. (2015). Kaynaştırma sınıfı öğretmenlerinin sınıf yönetimine ilişkin görüşleri ve gereksinimleri. Ankara Üniversitesi Ĕ̆itim Bilimleri Fakültesi Özel Eğitim Dergisi, 16(3), 215-236. 
Ataman, A. (2005). Özel gereksinimli çocuklar ve özel eğitim. Özel gereksinimli çocuklar ve özel eğitime giriş. Ankara: Gündüz Eğitim ve Yayıncllı.

Atay, M. (1995). Özel gereksinimli çocukların normal yaşıtları ile birlikte eğitim aldıkları kaynaştırma programlarna karşı ögretmen tutumları üzerine bir inceleme. Yayınlanmamış doktora tezi, Hacettepe Üniversitesi, Ankara.

Batu, E. S. (2010). Factors for the success of early childhood inclusion \& related studies in Turkey. International Journal of Early Childhood Special Education, 2(1), 57-71.

Bek, H.,Gülveren, H. ve Başer, A. (2009). Sınıf öğretmeni adaylarının kaynaştırma eğitimine yönelik tutumlarının incelenmesi. Uşak Üniversitesi Sosyal Bilimler Dergisi, 2(2), 160-168.

Cavkaytar, A., ve Diken, H. I. (2005). Özel eğitime giriş. Ankara: Kök Yayıncllk, 11-12. Çakıroğlu, O. (2016). Özel eğitimde temel kavramlar. V. Aksoy (Ed.), Özel eğitim içinde (s. 1-19). Ankara: Pegem Akademi.

Ergül, C., Baydık, B., ve Demir, Ş. (2013). Özel eğitim öğretmen adaylarının ve öğretmenlerinin zihin engelliler öğretmenliği lisans programı yeterliklerine ilişkin görüşleri. Kuram ve Uygulamada Eğitim Bilimleri, 13(1), 499-522.

Ersoy, F. (2017). Fenomenoloji. A. Saban ve A. Ersoy (Eds), Eğitimde Nitel Araştırma Desenleri içinde (s. 81-134). Ankara: Anı Yayınclık.

Firat-Durdukoca, Ş. (2015). Özel eğitim dersine yönelik tutum ölçeğinin geliştirilmesi. Turkish Studies, 10(11), 651-666.

Kayhan, N., Şengül, A. ve Akmeşe, P.P. (2012). İköğretim birinci ve ikinci kademe öğretmen adaylarının kaynaştırmaya ilişkin görüşlerinin incelenmesi. Eğ $i-$ tim ve Öğretim Araştırmaları Dergisi, 1(3), 268-278, ISNN: 2146-9199.

Kim, J. R. (2011). Influence of teacher preparation programmes on preservice teachers' attitudes toward inclusion. International Journal of Inclusive Education, 15(3), 355-377

Girmen, R (2007). İlköğretim öğrencilerinin konuşma ve yazma sürecinde metaforlardan yararlanma durumları. Yayımlanmamış doktora tezi, Anadolu Üniversitesi, Eğitim Bilimleri Enstitüsü, Eskişehir

Gök, G., ve Erbas, D. (2011). Okul öncesi eğitimi öğretmenlerinin kaynastirma eğitimine ilişkin görüşleri ve önerileri International Journal of EarlyChildhood Special Education, 3(1), 66-87.

Gökdere, M. (2012). A comparative study of the attitude, concern, and interaction levels of elementary school teachers and teacher candidates towards inclusive education. EducationalSciences: Theory and Practice, 12(4), 2800-2806. 
Gözün, Ö., ve Yıkmış, N. (2004). İköğretim müfettişlerinin kaynaştırma uygulamasına ilişkin görüş ve önerileri. Ankara Üniversitesi Ĕ̆itim Bilimleri Fakültesi Özel Eğitim Dergisi, 5(2).

İlgar, Ş. (2017). Öğretmen adaylarının özel gereksinimli öğrencilerle ilgili farkındalığının incelenmesi: İÜ Hasan Ali Yücel Eğitim Fakültesi örneği. HAYEF Journal of Education, 14(1), 313-338.

Millî Eğitim Bakanlığı. (2015). Millî Eğitim Bakanlığı 2014 yılı faaliyet raporu. Ankara.

Miles, M. B., Huberman, A. M., ve Saldana, J. (2014). Qualitative data analysis: A methodsourcebook. (3rd edition). ThousandOaks, CA: SAGE,

Orel, A., Zerey, Z. ve Töret, G. (2004). Sınıf öğretmeni adaylarını kaynaştırmaya yönelik tutumlarının incelenmesi. Ankara Üniversitesi Eğitim Bilimleri Fakültesi Özel Ĕ̆itim Dergisi, 5(1), 23-33.

Özbaba, N. (2000). Okul öncesi eğitimcilerin ve ailelerin özel eğitime muhtaç çocuklar ile normal çocukları entegrasyonuna (kaynaştırılmasına) karşı tutumları. Marmara Üniversitesi, Eğitim Bilimleri Enstitüsü, İstanbul.

Patton, M. Q. (2014). Nitel araştırma ve değerlendirme yöntemleri. M. Bütün ve S.B. Demir (Çev eds.). Ankara: Pegem Akademi.

Sarı, H. (2002). Etkili bir öğretim için bir öğretmenin planlaması gereken stratejiler. Eğitime Yeni Bakışlar. 227-248.

Saraç, T., ve Çolak, A. (2012). Kaynaştırma uygulamaları sürecinde ilköğretim sınıf öğretmenlerinin karşılaştıkları sorunlara ilişkin görüş ve önerileri. Mersin Üniversitesi Eğitim Fakültesi Dergisi, 8(1), 13-28.

Soyyiğit, T. (2013). 'Simıföğretmenlerinin değer tercihleriyle kaynaştırmaya yönelik tutumları arasındaki ilişkininin incelenmesi: Pendik İlçesi örneği. Yüksek Lisans Tezi, Yeditepe Üniversitesi, Sosyal Bilimler Enstitüsü, İstanbul, Türkiye.

Şahbaz, U., ve Kalay, G. (2010). Okul öncesi eğtimi öğretmen adaylarının kaynaștırmaya ilișkin görüsslerinin belirlenmesi. Mehmet Akif Ersoy Universitesi Egitim Fakultesi Dergisi, 10(19), 116-135.

Şahin, F. ve Güldenoğlu, B. (2013). Engelliler konusunda verilen eğitim programının engellilere yönelik tutumlar üzerindeki etkisi. Amasya Üniversitesi Eğitim Fakültesi Dergisi, 2(1), 214-239.

Sucuoglu, B., Bakkaloglu, H., Iscen Karasu, F., Demir, S., ve Akalin, S. (2014). Preschool Teachers' Knowledge Levels about Inclusion. EducationalSciences: TheoryandPractice, 14(4), 1477-1483.

Uçuş, Ş.(2016).Sınıf öğretmeni adaylarının ve okul öncesi öğretmeni adaylarının özel eğitime ilişkin metaforik alglarının incelenmesi. Adryaman Üniversitesi Ĕ̆itim Bilimleri Dergisi, $6(2), 360-388$ 
Varlier, G., ve Vuran, S. (2006). Theviews of preschool teachers about integration. EducationalSciences: TheoryEPractice, 6(2), 578-585.

Vuran, S.(2013). Özel eğitim. Ankara: Maya Akademi.

Yazıcıoğlu, T. (2019). Öğretmen adaylarinin özel eğitim dersine yönelik tutumlarınu incelenmesi. III. Uluslararası Eğitim Bilimleri ve Sosyal Bilimler Sempozyu$m u$, Nevşehir.

Wiersma, W. (1995). An introduction: Researchmethods in education. Boston: Allyn Bacon Inc.

\section{Kaynakça Bilgisi / Citation Information}

Altındağ Kumaş, Ö. ve Süer, S. (2020). Öğretmen adaylarının özel eğitime ilişkin metaforik algıları. OPUS-Uluslararası Toplum Araştırmaları Dergisi, 16(28), 1076-1101. DOI: 10.26466/opus.676175 